\title{
Human-Reluctant Modernity: The Reason of Tommy Wilhelm's Painful Isolation in Saul Bellow's Seize the Day
}

\author{
Md.Morshedul Alam \\ Lecturer in English Language and LiteratureDept. of English Language and LiteratureInternational Islamic \\ University ChittagongChittagong, BangladeshCell
}

\begin{abstract}
In English literature, men of modern civilization are shown on many occasions as experiencing the futility and misery of modern existence. In this regard Saul Bellow's Seize the Day is worth-mentioning. In this text Bellow has shown a man's indescribable sufferings in the shape of excruciating isolation in a capitalistic American society of modern civilization. Inversing the right course of action, in a capitalistic or modern society matters or money are given far more importance than human affairs and humanity. This inversion predictably gives rise to acute isolation and sufferings. In accordance with it, Saul Bellow in Seize the Day depicts the protagonist Tommy Wilhelm, a modern man, as finding himself in a diametric alienation resulting from the absence of meaningful relations with family, society, workplace and state. This paper aims at exploring how in Saul Bellow's Seize the Day a modern man Tommy Wilhelm becomes the victim of severe sufferings due to allout isolation in a human-reluctant modern society where modernization reconstructs a human self and human society replacing irreplaceable human virtues with material considerations.
\end{abstract}

Key Words: isolation, a modern man, money, self, society, material considerations

In Saul Bellow's Seize the Day the protagonist Tommy Wilhelm is a victim of Modernism by being isolated from society and state. The situation worsens when there is the severe lack of human relationship. That is why frustration arises and problem remains unsolved. The novel exhibits Tommy Wilhelm amidst chaos by being separated from his wife and children and also at odds with his materially successful father. Moreover, he remains without satisfactory employment and undergoes marginal living both financially and emotionally. During the course of the day Wilhelm remembers his past mistakes, notices his present confusions and sinks more deeply in despair and pessimism.

Actually the sufferings of a modern man originate in modernity that ignores the issue called human but upholds matters like money, wealth, power, status and fame. Likewise Tommy Wilhelm of Saul Bellow's Seize the Day suffers in the modern society of America. Thus the reason of the sufferings of a modern man is matterfriendly modernity. This paper tries to explore how in Saul Bellow's Seize the Day modernity turns out to be the reason of Tommy Wilhelm's painful isolation from family, society, job, state and religion.

Tommy's painful isolation and failure of life are actually the outcome of Capitalism that operates under the guise of modernity. Capitalism is laisez faire signifying that anything is valid in trade and commerce for the sake of profit. Clearly, when the objective of trade and commerce is not service to mankind, it is bound to put majority of the people under tremendous torture. Tommy represents that tortured humanity which has a dimension of painful isolation in a capitalist society of New York, New York which is a city "of complexity and machinery, bricks and tubes, wires and stones, holes and heights" (83). Scott Fitzgerald in his novel The Great Gatsby has portrayed one whole locality featuring the tortured humanity in the capitalistic country America during 1920s. The name of the locality is given as the Valley of Ashes. Here the ashes, the waste material produced from a power generating plant supplying power to New York's upper class, is dumped. The valley, inhabited by the lower class, is of ash colour everywhere. Here based on the ashes, most of the people have invented one means of earning livelihood. That is, the waste product of the upper class's luxury is tragically becoming the means of livelihood for the lower one. Fitzgerald writes,

This is a valley of ashes-a fantastic farm where ashes grow like wheat into ridges and hills and grotesque gardens; where ashes take the forms of houses and chimneys and rising smoke and, finally, with a transcendent effort, of ash-grey men, who move dimly and already crumbling through the powdery air. (29) Obviously, the majority of the 1920's American populations are shown as alienated, deprived and isolated in capitalistic America. Similar is the condition of Tommy Wilhelm of Seize the Day in post-World War II America. Capitalism can at best establish "legal humanism" meaning that actions of humanity are something determined by the state. This is how issues of humanity which are innate and natural become artificial and economic interest-based always serving the interest of the upper, middle and the ruling class. A capitalistic 
society does not give birth to "natural humanitarian values" which is a must for the smooth functioning of a society (Khan, 2008: 44). If these values were there, Tommy would never have to suffer.

Tommy is victimized in a society of modernity. Tommy's victimization begins with the estrangement between him and his father. His father, Dr. Adler refuses to be kind or helpful to his son. He sees his son as a failure in every sense of the world. Adler is a man whose thoughts and actions are reduced to money and to inanimate law and order. The role played by the father here can be played by a son elsewhere in capitalist America. That is why Bellow writes, "The fathers were no fathers and the sons no sons" (84). Thus the plight of an individual in a highly commercial society is explored in Seize the Day. In this way the society where Tommy Wilhelm is living is based on the extreme forces of materialism with utmost disregard for humans, even for family.

The society constantly pushes Wilhelm to obtain material success by any means. This push results in a gap between Wilhelm's desire and reality. It has been his foolishness due to the pressure of modernity that he wants to become an actor just to get success though it is against his parents' will. He thinks, "He was to be freed from the anxious and narrow life of the average" (23). Without knowing the actual truth of the screen test, Wilhelm rushes out to Hollywood, changes his name and barely survives as an extra. Here Wilhelm actually fails in the capitalistic competition of the modern world.

In Capitalist America, how much a person is materially successful and efficient to represent him as a successful individual from materialistic point of view is essential? In such a matter-loving society right, wrong, truth and lie are insignificant in the sense that truth may be declared as lie and vice versa if the cause of materialistic benefits so demand. Matigari and Ngugi say, "The world is turned upside down, but it must be set right again. For I have seen that in our hand today lies is decreed to be the truth and the truth decreed to be lie" (5). The only surviving aim of each American is the pursuit of money and success. The person who fails to reach his goal is considered as an alienated individual. Society makes Wilhelm an individual and alienates from others.

Willy Loman, the character of Arthur Miller in Death of a Salesman (1949), seems to be the twin brother of Wilhelm as they are mostly alike in their job, life speculation and cause of their catastrophe, who cannot stop their respective inevitable downfalls. Like Wilhelm, Willy Loman feels intensity of emotion, simplicity of heart and considers the world to be so. Both Willy and Wilhelm are nearly similar when we think about their cause of failure and their ultimate ends. He believes personal attractiveness is enough with a view to attaining success in life. As in Death of Salesman we hear Willy says to Biff, "Because the man who makes an appearance in the business world, the man who creates personal interest, is the man who gets ahead. Be liked and you will never want" (25-26). Both Willy and Wilhelm are forced to make mistakes in their life and these very mistakes turn them away from their family and bring tragic consequences. Consequently, Wilhelm is to be murdered by Tamkin because of money. In the same way, Willy commits suicide believing the insurance policy of $\$ 20,000$ will be very helpful for his family. In an adverse anti-human perspective created by modernity, one Willy is murdered physically and one Wilhelm psychologically.

A true human being does not dwell long on insecurities or fears, but tries to proclaim that he exists. $\mathrm{He}$ might tend to surrender or fluctuate at times but surely he will just get back to conquer the insecurities and fears because "The life of human beings is reflected by three things, feelings, thoughts and deeds" (Khan, 1990: 35).

Adler stands as the typical American materialistic father. When Wilhelm appears at the door of his father seeking compassion and assistance, he has furiously been rejected. Then Adler says, "I will see you dead, Wilky, by Christ; before I let you do that to me away from me now. It is torture for me to look at you, you slob!" (110). Thus Tommy's insecurities and fears of life intensify.

Adler eschews the heartiest cry of Wilhelm. He could have stretched his helping hand to his son or at least give him convulsion. It may have happened that Wilhelm avoids the prohibition of his parents to join in Hollywood. But he might have obeyed the suggestion of Adler. Perhaps it was Wilhelm's emotional stage when he would like to be an actor. If Adler stood by Wilhelm as a guardian, mentor, advisor and affectionate father, Wilhelm would not incline to the shrewd person Tamkin. We see that Wilhelm can comprehend what the real face of Tamkin is, but forgets instantly thinking that - "At least Tamkin sympathies with me and tries to give me a hand, whereas Dad does not to be disturbed" (11). This is Wilhelm's struggle to establish his existence.

Wilhelm, rejected by his own father, helplessly throws himself on the mercy of a number of fatherly figures. The most significant among them is Dr. Tamkin. When Wilhelm is deprived from his father's love and affection, he then sets himself in quest of a father- figure who can understand and love which is why he becomes an easy victim of Tamkin. Tamkin can conceive the heartiest agony of Wilhelm and lacking in his life and shows love and affection for Wilhelm to make him trustworthy. Eventually, Tamkin becomes Tommy Wilhelm's spiritual father. Wilhelm looks on him as an ideal Father, who understands the relationship of fathers and sons though later on he discovers that he is both narcissistic and materialistic. In this manner, Wilhelm becomes a tragic figure as he tries to feel his existence as a true human being with "feelings, thoughts and deeds" (Khan, 1990: 35). 
This is how Wilhelm, who still shares many of the characteristics of a true human being, cannot cope with his surroundings dictated by modern men. Wilhelm does suffer, and it is to such an extent that due to terrible isolation Tommy feels himself as a howling wolf. Tommy mentions that in New York city where he is born and brought up, activities and objects to alienate or isolate a person are very much present for which an isolated person can no longer regard himself as a human being. Thus, Tommy, in a society of people indifferent to others' sufferings, thinks he laments like an wolf at night to give an outlet to his agonized feelings. The severe isolation does not match with a man and, so, he considers himself a wolf. Tommy says, "If you only knew one percent of what goes on in the City of New York! You see, I understand what it is when the lonely person begins to feel like an animal when the night comes and he feels like howling from his window like a wolf" (67). This isolation is the doing of modernity, the prescribed lifestyle and concept of life propounded by economic system called Capitalism.

Modern society ponders over the hard inanimate world of money, selfishness and exploitation where feelings, emotions and morality or rationality have no significance. Here Wilhelm's passionate outburst is significant. He says, "No, but you hate me. And if I had money you would not. By God you have to admit it. The money makes the difference" (55). This discrimination among human beings would not occur if money and wealth that are connected with the physical self of a man were not the sole concern of modernity. Modernity could look upon men as beings which they really are. But the West, with its concept of modernity, reduces men and considers them as "social animals" or "social creatures". (Khan, 2013: 41, translation mine). When men are "social animals", they will be tremendously self-centred never thinking of higher epistemology related to their beginning and their Creator. In this discussion scholar Syed Hossain Nasr is also vitally relevant. Joseph E. B. Lumbard, referring to Nasr's view on Modernity, criticizes modern civilization and writes, “...the age of modernity, which makes of man an earthly creature responsible to none but himself and thus detached from his Center and ignorant of his Origin, is the lowest kind of civilization" (180)

Obviously, modernity cannot provide greater or holistic welfare even to the selected few who are deemed as gainers. Their range of life and mental horizon turn narrow.

By emphasizing only on the physical pleasure and comfort of a person, modernity inspires a man to be selfish. Resultantly, men are like some scattered islands having no human relationship and communication among them. But in conversation they pretend that they are perfectly happy with no lack of anything and conceal the miserable reality. But pretension cannot keep conversation smooth and lively for long. Continuity disrupts. This scenario applies to Tommy though he is not a modern man in complete sense. It is vindicated when we look at Wilhelm's conversation with the newspaper vendor Rubin. It is so commented, "When it came to concealing troubles, Tommy Wilhelm was not less capable than the next fellow" (3). The two pretend that they are intimate while one clearly knows the real condition of another's life. About those real conditions they mention nothing in their conversation. They hide. Wilhelm says, "none of these could be mentioned and the great weight of the unspoken left them little to talk about" (6).

Wilhelm's unsuccessful conversation also indicates that in a modern society people have their individualized expression articulated from his selfish position that is hardly understood by others. Bellow writes, "Every other man spoke a language entirely his own, which he had figured out by private thinking-he had his own ideas and peculiar ways" (83). Then Bellow writes, You had to translate and translate, explain and explain, back and forth, and it was the punishment of hell itself not to understand or be understood, not to know the crazy from the sane, the wise from the fools, the young from the old or the sick from well. The fathers were no fathers and the sons no sons. You had to talk with yourself in the daytime and reason with yourself at night. Who else was there to talk to in a city like New York? (83-84)

In modern civilization men's inner qualities like love, sympathy, emotion, commitment and sense of gratitude that are integral to their human identity have faced extinction. If with the yardstick of money, which is the only one modernity has possessed, something is valueless, that will completely be ignored. When this materialistic approach is predominant in Seize the Day, we see the relationship between Wilhelm and his wife Margaret is not functioning. Wilhelm, finding no other alternative, tries to divorce but Margaret does not permit it. Margaret deliberately prolongs the process because by doing so she can be financially even more benefitted. Ceated by Tamkin, Wilhelm says to his wife, "I am at the end of my rope and feel that I am suffocating. You do not want to be responsible for a person's destruction... I feel I'm about to burst" (113-114). But his heartfelt agony does not help to shake her heart a bit.

The common tendency of modern people is to ponder over the present not past or future. They believe in carpe diem, that is, to enjoy the present. This modern tendency is clarified by the mysterious doctor when he says "The past is no good to us. The future is full of anxiety. Only the present is real - the here-and-now. Seize the day" (66). Adler, Margaret and Tamkin belong to that modern group of people in a modern state.

When Adler, Margaret and Tamkin are concerned with regard to Wilhelm, we may say that Capitalism of modern society degrades human behavior and relationship. The traditional ways of life like marriage, conjugal life, family and fellow-feeling have become secondary where earning money and keeping pace with 
the changing money-mongering world become first priority for all. The traditional values, norms, customs, traditions have been quite insignificant before capitalistic mentality of the modern people. It is disastrous though initially and apparently delightful. Its reflection we see in The Wasteland by T. S. Eliot. Here, Phlebas, a young and rich merchant reaches the zenith of success in business. But he spends most of his life in sea for the purpose of business away from human society and his own human life. So his action can be marked as materialistic. Ultimately, he pays the price. He dies by drowning in the sea. Eliot writes in the section called "Death by Water",Phlebas, the Phoenician, a fortnight dead, Forgot the cry of gulls, and the deep sea swell And the profit and loss. A current under sea Picked his bones in whispers. As he rose and fell $\mathrm{He}$ passed the stages of his age and youth Entering the whirlpool. (2157)

So, in a modern society, one Phlebas may appear to be happy for being materially successful but actually he will suffer physically or mentally in the long run. This is inevitable. Another Wilhelm will suffer from the beginning till the end by being a failure from materialistic perspective. We find Wilhelm's complete helpless and deplorable condition by the end of the book when he looses his wife and money. His sobs and tears do not have any value before the materialistic and money-centred society. After the denial of his father, he wanders desperately into Jewish chapel and encounters what he least needs, a corpse, that is, dead hope and dead dream. Bellow writes,

The flowers and lights fused ecstatically in Wilhelm's blind, wet eyes; the heavy sea-like music came up to his ears. It poured into him where he had hidden himself in the center of the crowd by the great and happy oblivion of tears. He heard it and sank deeper than sorrow, through torn sobs and cries toward the consummation of his heart's ultimate need". (118)

In this modern or capitalist society, Wilhelm's deprivation and alienation take the form of something heavy upon his shoulders. The extremity of the weight makes Wilhelm think of the issue as mystery. And the mystery is irresolvable. Bellow writes,

The spirit, the peculiar burden of his existence lay upon him like an accretion, a load, a hump. In any moment of quiet, when sheer fatigue prevented him from struggling, he was apt to feel this mysterious weight, this growth or collection of nameless things which it was the business of his life to carry about. (38-39)

We can repeat here that Capitalism means laisez faire, that is, for commercial benefit in business anything can be done. So, it does not matter if the codes of morality or humanity are violated or people suffer once one business man achieves his commercial benefit. So, torture or deprivation is validated by Capitalism or Modernity. From micro to macro level, this is the scenario. Economist Masudul Alam Choudhury opines, "While the economic problems of a fortunate section of mankind may be solved, yet these will continue to be a dark reality at an immense cost of social and political deprivation of many" (2).

One who has the mindset to be sincere to his own family depriving neighbours does not actually have regard for the cause of universal humanity. For this, he can deprive any time any member of his own family. Similar is the case with the West and America. With their concept of Modernity or Capitalism, they put a large population of the world under severe deprivation like hunger and other crisis like civil war. One example will authenticate the kind of role they play. Lee, one South Korean farmer, representing the total farmer community of the world, appealed to World Trade Organization (WTO) which was to include agriculture in its controle in Kankun Conference in Mexico saying that agriculture had to be kept beyond WTO's controle because such measure was sure to destroy a farmer's economic freedom worsening the situation of his poverty. To strengthen his appeal, Lee even committed suicide. But WTO, led mostly by the USA and Europe, did not listen.

This is how when they behave especially with the third world countries of the world, they behave the same with many citizens of their own countries. Among those citizens, Wilhelm of America as read in Seize the Day is one. Tamkin tactfully forces Wilhelm to invest his last means in lard business. But the exploiter Tamkin shrewdly escapes with all these money. This Tamkin is a capitalist or modern business man who orients readers with the idea of murder in money making. He gives the idea saying, One fact should be clear to you by now. Money-making is aggression. That's the whole thing. The functionalistic explanation is the only one. People come to the market to kill. They say, I am going to make a killing. ' It's not accidental. Only they haven't got the genuine courage to kill, and they erect a symbol of it. The money they make a killing by fantasy. (69)

Apart from the detrimental ones, most of the components of tradition are benign and useful for mankind as they stand the test of time. Modernity breaks away from this tradition and causes chaos. Scholar Martin Lings explores two types of chaos: one is the "fluid chaos" caused by the concepts and ideas of free world and another is "rigid chaos" caused by the utilitarian part of modern society (45). In comparison with both "rigid chaos" and "fluid chaoa", ancient time was better. People would abide by set rules of society which aimed at greater welfare of all. Lings says, "By contrast with both, the ancient world was always an order, that is, a hierarchy of concepts, each at the level that rightly belongs to it" (45) A modern man lives in an illusion created in his narrow sphere of self-serving aims. He degrades himself to the level of animals denying his higher purpose of concentration on the Creator. This is also the viewpoint of Hossain Nasr. Referring to Nasr, Lumbard 
says, He seeks to expose the fallacies upon which modernism is founded in order to save contemporary man from a world that denies his pontifical nature, reducing him to his rational and animal aspects and leaving him to wander in a desacralized wasteland, oblivious to his Origin and estranged from his true self, living on the periphery with no orientation towards the Center. (182) As Modernity is one dimensional because of its concentration only on physical demands while human life is multi-dimensional, modernity is human-reluctant if overall human well-being is concerned. And obviously, Wilhelm of New York suffers painful isolation resulting from alienation and deprivation of a modern society of Capitalism. In other words, Modernity is responsible for the pitiful loneliness of him. There could be one holistic approach from the part of the West. That could provide true happiness to people including Wilhelm.

\section{WORKS CITED}

[1] Bellow, Saul. Seize the Day, Penguin Books, USA, 1996.

[2] Choudhury, Masudul Alam. "The Dynamics of Shari'ah and the World-System”, J.KAU, Islamic Econ., Vol. 23, No. 2, pp: 197-225, 2010.

[3] Eliot, T. S. Norton Anthology of English Literature, ed. M.H. Abrams and Stephen Greenblatt, eighth edition, 1962.

[4] Fitzgerald, F. Scott. The Great Gatsby, the Penguin Group, 1926

[5] Matigari, Ngugi. A Non Materialist Discourse and Post Modernism.Vol. I, II-2005, 5.

[6] Khan,Muin- Ud-Din Ahmad. Political Crisis of the Present Age. Baitush Sharaf Islamic Research Institute, Chittagong.pp12-15,1990.

[7] _ _ . "Typology of Knowledge in the East and the West", part II, $21^{\text {st }}$ Cebtury Challenges for Global Muslim Community, ed. Ahmed Farid, Niaz Ahmed Khan, Renaissance Foundation for Human Resource Management, Dhaka, 2008

[8] _ _ . Jukti Totwer Sworup Shondhane,Prachyo bonam Pratichoy.(In search of the Nature of Reason and Principle: East versus west), October,2013.

[9] Lings, Martin. Ancient Beliefs and Modern Superstitions. 1980

[10] Lumbard, Joseph E. B. "Tradition and Modernity: Christian and Muslim Perspectives", Georgetown University Press, 2013

[11] Miller, Arthur. Death of a Salesman, Penguin London, 1948. 